This item was submitted to Loughborough's Research Repository by the author.

Items in Figshare are protected by copyright, with all rights reserved, unless otherwise indicated.

\title{
Permissiveness on trial: Sex, drugs, rock, the Rolling Stones, and the sixties counterculture
}

\section{PLEASE CITE THE PUBLISHED VERSION}

https://doi.org/10.1080/03007766.2018.1439295

\section{PUBLISHER}

(C) Taylor \& Francis (Routledge)

\section{VERSION}

AM (Accepted Manuscript)

\section{PUBLISHER STATEMENT}

This is an Accepted Manuscript of an article published by Taylor \& Francis in Popular Music and Society on 17 January 2019, available online: http://www.tandfonline.com/10.1080/03007766.2018.1439295.

\section{LICENCE}

CC BY-NC-ND 4.0

\section{REPOSITORY RECORD}

Collins, Marcus. 2019. "Permissiveness on Trial: Sex, Drugs, Rock, the Rolling Stones, and the Sixties Counterculture". figshare. https://hdl.handle.net/2134/31909. 


\section{Permissiveness on Trial: Sex, Drugs, Rock, The Rolling Stones, and the Sixties}

\section{Counterculture}

Marcus Collins (marcus.collins@lboro.ac.uk)

Abstract: This article examines how a 1967 scandal involving drug-taking among popular musicians catalyzed a debate between its principal participants - the Rolling Stones, politicians, the press, the courts, and the counterculture - about what was and was not permissible in matters of personal conduct, individual liberty, and social responsibility. These discussions reveal the provisional, contested, and circumscribed quality of permissiveness in 1960s Britain, which was nonetheless becoming a more diverse and pluralistic society. Permissiveness was not a monolithic cause and existing models of it — whether they stress its marginality or its magnitude, its malign or benign effects - risk simplifying a constellation of behaviors and beliefs championed by different interests for different reasons.

Keywords: Rolling Stones; counterculture; permissiveness; drug use; sixties; Britain; popular music

On the evening of 12 February 1967, the police raided a house party hosted by the Rolling Stones' guitarist Keith Richards at his country residence of Redlands. They found three varieties of drug on the premises. A jacket belonging to Richards' bandmate Mick Jagger contained four amphetamine tablets. Cannabis was found in the possession of an American associate of theirs, David Schneidermann, together with traces of cannabis resin on some of Richards' possessions. Heroin jacks were also discovered on the person of their close friend, the art dealer Robert Fraser. Schneidermann escaped justice by fleeing abroad, but the other three were duly charged with drug offenses: Jagger for unlawful possession of amphetamines, Fraser for unlawful possession of heroin and Richards for permitting his premises to be used 
for the smoking of cannabis or cannabis resin. They were tried at the end of June. All were found guilty and sentenced to terms of imprisonment, though Richards and Jagger were soon released on bail pending their appeal. A month later, on 31 July 1967, the appeals court quashed Richards' conviction, upheld that of Jagger while suspending his prison sentence and left the verdict on Fraser unchanged.

The Redlands Affair's salacious mix of sex and drugs and rock and roll generated petitions, editorials, documentaries, parliamentary questions, demonstrations, records, artwork, a popular book (Hewat) and an opinion poll in which only $6 \%$ of the general public expressed no opinion on Jagger's imprisonment (Longmuir 1). Our factual knowledge of the Affair has deepened considerably since this time thanks to the publication of autobiographies (Richards and Fox; Faithfull and Dalton; Rees-Mogg, Memoirs), biographies (Bokris; Vyner; Wheen) and Wells' comprehensive narrative account. Yet interpretations of its meaning and significance have remained remarkably constant over the past half century.

Then and now, permissiveness provided the main conceptual framework for understanding the Redlands Affair. Permissiveness was defined in 1967 by the editor of International Times (IT) as the doctrine that "the individual should be free from hindrances by external Law or internal guilt in his pursuit of pleasure so long as he does not impinge on others" ("Bust" 4). The term gained currency at the time - and to this day "can hardly be avoided ... [i]n any study dealing with material on social issues in this period" (Jarvis 9; see also National Deviancy Council; Newburn; Marwick, Sixties; Davies; Collins, The Permissive Society; Weeks; Mort, Capital Affairs; Mort, "Permissive Society"; Harrison ch. 9; Addison chs 7 and 11) — because it appeared to explain and connect a concatenation of changes in sixties Britain. These included the liberalization of laws concerning personal conduct, the "sexual revolution," the weakening of traditional moral codes, the emergence of alternative and countercultural lifestyles, and the prominence of new and vital cultural forms. 
The Redlands Affair became the defining scandal of Britain's "Summer of Love" because it threw new light onto all of these phenomena and engendered debate about how permissive Britain had, could, or should become.

Contemporaneous commentary and recent analysis on the Affair divide into four broad schools of thought — conservative, radical, liberal, and skeptical—which correspond to differing conceptions of permissiveness. Conservative moralists in 1967 equated permissiveness with license: that "smell of decadence" detected by the Daily Mail (Furlong 6) as emanating from the Redlands mansion. The editor of the paper which instigated the bust, the News of the World, claimed that the Stones received succor from a permissive establishment (quoted in Hewat 103), which was prepared to "excuse any aberration and condone every outrage against normally accepted standards of conduct." Jagger appeared two decades later as the personification of moral and cultural decadence in Allan Bloom's influential The Closing of the American Mind (1987). Bloom's idea that Jagger "legitimated drugs" (78) has been elaborated by Peter Hitchens into a fully-fledged ideology of "Jaggerism" (War ch. 14). According to Hitchens, Jaggerism's doctrine of "total sovereignty over our bodies" sought to overthrown the "religious and conscience-based moral system" upon which society was built (War 111). The tolerance extended to Jagger by the "liberal elite" (Brief 212) during the Redlands Affair is in Hitchens' eyes tantamount to moral betrayal.

The notion that the Redlands Affair represented a victory for the counterculture found little favor among sixties radicals. $O z$ magazine saw the Affair as part of a wholesale "Square Backlash" to be placed alongside the prosecution for obscenity of Hubert Selby Jr.'s novel Last Exit to Brooklyn and the rough passage accorded to bills liberalizing abortion and male homosexuality (“How I Jailed Jagger”). Richards' assertion in 1969 (quoted in Logan 4) that the police were "more and more concerned with how you live" resembled a rough draft of the 
more sophisticated models of social control developed by the Centre for Contemporary Cultural Studies. The Redlands Affair appeared in the CCCS' seminal Policing The Crisis (Hall et al. 1978) as the centerpiece of a "great English 'panic' about drug use” (239) in 1967, in which Jagger served as a folk devil for a broader attack on youth subculture. "No figure was more designed to fit the stereotype and trigger moral alarm" than Jagger, its authors claimed (240). This model has subsequently been developed by Martin Cloonan, who pinpoints 1967 as the beginnings of "a backlash against the permissiveness which appeared to have pop at its core" (6). It also appears in Richards' and Faithfull's autobiographies, which depict the Affair as the decisive moment when the establishment turned against the counterculture.

A liberal interpretation of the Affair was championed by one of the major participants in its events, Times editor William Rees-Mogg, who credited himself with advocating clemency for Jagger and for engaging in dialogue with the leaders of the rising generation (Rees-Mogg, Memoirs ch. 9). David Fowler supports this approach by refuting claims of an Establishment conspiracy and generational conflict. He contends that In June and July of 1967 ... Mick Jagger emerged triumphantly as a charismatic, articulate, thoughtful and even intellectual youth whose image with the middle classes of the Home Counties was transformed from fear and contempt to undoubted respect.

From this perspective, the Redlands Affair represents a victory for what Arthur Marwick (Sixties 290) dubbed “measured judgement." It can take its place alongside other permissive milestones of 1967: a year characterized by Stephen Brooke as "epochal" (11) and by Marwick as the "annus mirabilis" for permissive legislation (British Society 151).

A skeptical approach to the Affair's significance was taken by two of the earliest histories of pop, George Melly's Revolt into Style (1970) and Nik Cohn's Awopbopaloobop 
Alopbamboom (1969). Melly argued that the counterculture was not so subversive nor the state so repressive as each accused the other of being. He cited the fact that "only the right to smoke pot has stung the pop world into protest" as testament both to "the comparatively permissive attitude of the authorities" (119) and to pop music's limited challenge to the status quo:

Its only revolutionary value is in its insistence on personal freedom. This is certainly important, but the right to smoke pot or strip naked in public are not going to affect the structure of society. (119-20)

Nik Cohn blamed the "hysterical" attitudes of hippies and the police for turning "something so trivial" as cannabis into a "national obsession" (222). This line of argument has recently been pursued by Dominic Sandbrook, who portrays all parties as overreacting to the Redlands Affair. He views the Stones' belief that they were "scapegoats for the permissive society" to be "ridiculous" and characterizes them to have "often led much more conservative lives than people imagined" $(524,518)$ : a verdict endorsed by Dorian Lynskey's portrayal of the Stones as "Rock's Fake Rebels."

This article argues that none of these models satisfactorily accounts for the Redlands Affair nor for permissiveness as a whole. Conservative moralists are at a loss to explain why a putatively liberal Establishment did not decriminalize recreational drugs. Radical claims of an anti-permissive backlash face the converse problem of explaining away permissive reforms in other fields. $O z$ 's alarmist prophesy went unfulfilled, as the appeals court overturned the verdicts against the Stones and Last Exit to Brooklyn and the Abortion Act and Sexual Offences Act made it to the statute book in 1967. Liberal models exaggerate the rapprochement effected between the Stones and their sympathizers in positions of power, which was superficial and short-lived. The Stones and the counterculture remained detached 
from and incompatible with mainstream British society to a degree unacknowledged by skeptical accounts.

Whether they stress its marginality or its magnitude and its malign or benign effects, these four models tend to conceive of permissiveness as a single entity. This article offers a different interpretation by using the Redlands Affair to show that permissiveness was a portmanteau concept containing contradictions and competing interests. The first section explores the apparent paradox that the most permissive people in sixties Britain disputed the very existence of a permissive society and clashed with a state passing permissive reforms. The second section considers why anti-permissive legislation against recreational drug use was enacted in a decade when restrictions were relaxed on comparable private acts. The third section focuses on the Redlands Affair itself, when the actors described in the first section were prosecuted under the laws described in the second section. It indicates that none of the participants achieved their full objectives in the Affair, which was characterized by unforeseen outcomes. The fourth section shows how the divergent understandings of permissiveness held by the Stones, liberals, and the counterculture prevented the creation of a stable coalition for drug reform during and after the Redlands Affair. The attitudes and actions of the main players in the Redlands Affair - the Rolling Stones, the counterculture, politicians, the courts, and the media - are studied here using the sources generated by and about them. For the Stones, the article relies largely on interviews and their creative output; for the counterculture, on magazines and memoirs; for politicians, on Parliamentary proceedings; for the courts, on trial reports; and for the media, on coverage and commentary by broadcasters, newspapers, and periodicals.

\section{Permissiveness, the Stones, and the counterculture}


Popular music generated some of the most celebrated debates about permissiveness in sixties Britain (Collins, "I Feel Free"), from Dusty Springfield's opposition to apartheid, through Pete Townshend's guitar-smashing and Cliff Richard's evangelizing, to John Lennon's impiety, nudity, and adultery. The Rolling Stones were represented as permissive from the outset (for scholarship on the band, see Dick and Reisch; Staubmann; Barnes; Coates; Collins, "Sucking”; Faulk ch. 3; Whiteley ch. 5). After having released just a single single, they were described by the New Musical Express (Williams 8) as "believ[ing] in complete individuality and free expression." "Their music reflects this freedom," it added. Individualistic sentiments also appeared in their interviews, with Jagger (quoted in Paytress 78) stating that "We should all have the right to choose which way to live our lives," and in a series of anthems including "Get Off Of My Cloud," and "I'm Free” in 1965 and "Ruby Tuesday" in 1967. The Stones promoted sexual liberation in "Let's Spend the Night Together" and opposed social convention when criticizing marriage in "Sittin' on a Fence" and "Yesterday's Papers" (all 1967).

The Stones' loucheness was exploited by their manager Andrew Loog Oldham to create headlines, sell records and differentiate them from the Beatles (Harron 177-78; McMillian 35-37), but it was more than a marketing strategy. Jagger, Richards, and bandmate Brian Jones developed a coherent set of libertarian beliefs which encompassed the permissive causes of the day. Jagger saw the drug laws as being as outmoded as those which had hitherto criminalized attempted suicide and male homosexuality (World In Action) and Jones (quoted in Altham) denounced as immoral the persecution of homosexuality, abortion and drug-taking rather than the acts themselves. Decidedly less principled but no less permissive was the manner in which the Stones goaded straight society through confrontational and anti-social acts. Jagger announced that "We'll piss anywhere, man" when denied the use of a garage toilet (quoted in MacDonald 54), Richards flicked snot onto a 
buffet table (Alan Whittacker quoted in Paytress 63) and drummer Charlie Watts dropped fag-ends into other people's drinks (Keith Altham quoted in Sandford 79). They justified their actions as a challenge to petty restrictions imposed by an anti-permissive and conformist society. This was theme of their 1965 hit “(I Can’t Get No) Satisfaction” and of Jagger's comment (quoted in Dalton and Farren 130) that "I only got into rebellion because I wasn't able to do what I wanted ... I couldn't play here and I couldn't play there and I couldn't do this and I couldn't do that."

The Rolling Stones' combination of libertarianism and confrontationalism was exemplified in their attitudes to recreational drugs. Drug use was defended by Jagger as early as 1965:

I conduct myself as I think fit and what I do is my affair. In the same way I feel this should be the right of every teenager today. If they want to smoke, drink, swallow purple hearts and pills, then the decision is theirs. ("Mick Jagger" 9)

Cigarettes, alcohol, and amphetamines were pretty much the limit of what the Stones were taking at the time, but Richards (quoted in Greenfield) recalled that cannabis had become "common" by 1966 and he returned from the American tour that summer "with pockets full of acid." "In a matter of a few months," he recalled (quoted in Bokris 95), "drugs had become a major way of life."

The Stones took drugs for a number of reasons: to continue a long tradition among musicians and bohemians (see Shapiro), to cope with the pressures of touring and fame, to inspire them to new creative heights and, crucially, to escape from and protest against an unpermissive society. As Richards saw it (quoted in Loder), "something had to be changed, and that [taking drugs] was the quickest way of doing it — while you were waiting for a real change." A vicious cycle occurred, as drug use further alienated the Stones from the 
mainstream, both because it was criminalized and because its mind-expanding properties made the square world seem even more humdrum and insignificant.

The Stones started out in the early 1960s as marginal bohemians-cum-delinquents, but by 1967 found themselves immersed in a psychedelic music scene (Bromell ch. 3; DeRogatis; Whiteley; and Whiteley and Sklower) and surrounded by a whole community of like-minded souls. The counterculture or "Underground" constituted the closest thing in the sixties to a self-sufficient and self-governing (but not self-contained) youth subculture. IT's first editorial ("You" 8) encouraged its readers to exercise autonomy over themselves: "to be your own government" as well as "taking on governments." Permissive reform could not possibly satisfy them. They sought permission from no one and did not identify with a gradualist program which represented only a fraction of their ambitions. Moreover, in contrast to other groups attracting sympathy from permissive reformers-racial and sexual minorities, the unwillingly pregnant or the unhappily married — counterculturalists chose to be outsiders and gloried in their deviance.

But the freer the Underground sought to be, the more it ran up against the boundaries of the permissible. Few in the 1960s were willing to countenance the counterculturalists' vision of a pluralistic society liberated from moral orthodoxy. Nor were the authorities likely to indulge those who rejected their legitimacy and jurisdiction. They harassed its press, outlawed its radio stations, and targeted its psychoactive drugs, the use of which counterculturalists regarded as an initiation rite, a badge of membership and the most permissive of acts (see Willis; Young; Davis; Wilson, "Spontaneous Underground”; Weinhauer; Roberts; Farber).

\section{The illiberalism of drug legislation}


Politicians of the 1960s recognized that drug use shared many of the characteristics of other behaviors sanctioned by permissive reforms (see Dorn; Greenwood and Young). Like gambling, abortion, and sex between men, drug-taking was a consensual act generally undertaken in private. But drugs were not merely exceptions to the rule of permissive reform. In fact, the rules governing permissive legislation become clearer once we appreciate why drug users were subject to exceptionally severe treatment.

Legislators essentially had three options when dealing with such "victimless crimes." The first was decriminalization, which was enacted for male homosexuality and attempted suicide. The second option was regulation of the kind deemed suitable for abortion and offcourse betting. Repression was the third.

Decriminalization was ruled out in the case of drugs because their users failed to fulfil the criteria required of groups granted permissive reforms: of being responsible actors exercising informed consent without injuring others. Those taking drugs were considered incapable of giving informed consent because, being addled and addicted, they were devoid of free will. They were also increasingly young at a time when youngsters were adjudged to display responsibility only when acting in the same way as adults: the message of the 1967 Latey Report which recommended lowering the age of majority from 21 to 18 . When following their own path, as when taking recreational drugs, the young were branded immature, irrational, and in need of protection.

It was "the impressionable, the curious, the frustrated, and the demoralized" who took soft drugs, claimed Home Office minister Alice Bacon (1164), in total contradiction to the counterculture's self-image as an enlightened elite with sovereignty over themselves. Bacon (1164) portrayed drug-takers as not simply "immature," but anti-social. She condemned their broader opposition of "traditional values and social judgments of all kinds," (1164) much as 
Shadow Chancellor Iain Macleod (1562) included addicts among those "who have rejected our society and who reject us."

The second option — that of regulation — was deemed appropriate for amphetamines and heroin, both of which remained available on prescription (for amphetamine use, see Wilson "Mixing"; for heroin use, see Mold Heroin ch. 2). Yet this "British system" of drug control whereby doctors performed a gatekeeping role lost credibility in the 1960s. As Mold argues, recent writing has questioned the motives behind the "British system" and even disputed its existence (Heroin introduction and ch. 1),. However, it remains the case that many contemporaries (domestic and foreign) regarded Britain to be distinctive in its tendency to medicalize rather than criminalize hard drug users. A comparison between the first and second governmental reports on drug addiction indicates that the authorities were losing faith in drug-users acting responsibly under a regulatory system owing to an erosion of moral norms. In 1961, the committee members (Drug Addiction 9) expressed confidence that "social attitudes to the observance of the law in general and to the taking of dangerous drugs in particular" severely limited drug use. In 1965, however, they feared (Drug Addiction 41) that "The present trends, particularly in wider consumption of 'pep' pills, may foreshadow a significant change in public attitudes to the taking of dangerous drugs."

Repression was therefore politicians' standard response towards drugs, often justified in avowedly anti-permissive terms. The most famous denunciation of permissive drug policy was Home Secretary Jim Callaghan's vow (959) "to call a halt in the advancing tide of socalled permissiveness" when rejecting the decriminalization of cannabis in 1969. Yet he was merely following the lead of one of his predecessors as Home Secretary, the Tory Henry Brooke, who had introduced a bill "to deal with the current 'purple hearts' racket" in 1964 (311) as part of a raft of anti-permissive measures including restrictions on nightclubs and obscene publications. 
If politicians decided against being permissive, then they felt obliged to be highly repressive because - as with other private acts — drug use was hard to detect and control. They accordingly introduced draconian measures including the removal of general practitioners' powers to prescribe hard drugs and the granting of extensive police sanctions to stop and search suspects. They criminalized those taking drugs bought legally abroad and the owners of venues in which drugs were consumed. They refused to distinguish in legislation between possession and dealing or between cannabis and truly "dangerous drugs," and they enforced strict liability, which meant that under certain circumstances mens rea would not apply to those charged with drug offences.

Several pressures induced politicians to tighten drug laws in the 1960s. One was the spiraling number of arrests and convictions. Another was the proliferation of new varieties of drug on the market — including "sex juice," if The Times was to be believed ("New Drug" 5). A series of media exposés added to a sense of crisis reminiscent of the drugs scare of the 1920s (Kohn), with Conservative MP Bernard Braine noting (509) that "not a day passes without the Press reporting a police raid on a coffee bar or a sleazy club frequented by teenagers, or arrests for possession, or stories about pop stars and drugs." Adrian Bingham's observation that "[n]ewspapers competed to reveal the latest evidence of looser morals" (121) in the second half of the 1960s applies to drugs as well as sex. Besides the Redlands Affair, 1967 saw The News of the World exposing the drug habits of Donovan and the Moody Blues, ITN asking Paul McCartney whether he took LSD, and The Times printing Manfred Mann's call for a distinction to be made between hard and soft drugs (see Roberts 113-14; "Interview with Paul McCartney" [video]; Mann). Politicians expressed alarm, with Labour MP Laurie Pavitt (quoted in "Speed of Increase" 2) calculating that "One Rolling Stone is equal to about a hundred Malcolm Muggeridges in effect on young people." 
It is best to conceive of permissiveness as not so much an ideology among legislators as an option to be considered alongside paternalism and punishment. Drug-taking received the harshest treatment of the victimless crimes because it was perceived to be the newest and greatest threat, with the potential to warp the minds of a generation. Yet the policing of personal behavior relied on a moral consensus that held little sway in a small but significant minority of the population: then as now an intractable problem in the "war on drugs." Drug laws became ever more draconian during the 1960s, and it was under these severe new provisions that Jagger and Richards were to be convicted.

\section{Permissiveness on trial in the Redlands Affair}

Only one of the great court battles over permissiveness in Britain resulted in a clear-cut victory for liberalization. This was the first: the Lady Chatterley trial of 1961, which permitted Penguin to publish several hundred thousand copies of a hitherto illicit novel. Other trials resulted in defeats for liberalizers or ambiguous outcomes that dissatisfied them and conservative moralists alike.

The Redlands Affair was a case in point in that it confounded the intensions of all those involved. Before the bust, Jagger, Richards, and Faithfull worked on the assumption that they were safe enough taking drugs provided they did so in private. Their luck held prior to 1967 , but was increasingly jeopardized by media intrusions into their personal affairs. Donovan had been the first high-profile British pop star to be prosecuted for drug offenses after being filmed smoking cannabis in 1966, and The News of the World series on "Pop Stars and Drugs" in 1967 threatened to blow the lid on the drug-taking rampant in the pop world (Roberts 113-14). Jagger therefore seized the opportunity to sue the tabloid for its erroneous claim that he had admitted to taking acid (it was actually his bandmate Brian Jones who had boasted to a News of the World reporter about using cannabis.) 
Jagger's libel action was counterproductive because he committed "the Oscar Wilde mistake," as fellow defendant Fraser put it (quoted in Davis 188), of goading a powerful enemy to find evidence of his wrongdoing that would stand up in court. That evidence was not hard to find as the Stones associated with an assortment of shady characters, one of whom instigated the bust, and were hardly discreet in their drug use, loudly advertising it on their records to anyone versed in slang and puns. The ambiguous references to smoking and dreaming in 1965's "Satisfaction" and "Get Off Of My Cloud" were succeeded in 1966 by explicit references to Valium addiction ("Mother's Little Helper"), trips ("1 $19^{\text {th }}$ Nervous Breakdown") and getting high ("Doncha Bother Me"). Between The Buttons, released in January 1967, referred to bag searches (“Connection”) and being stoned (“Miss Amanda Jones"). Its closing track, "Something Happened To Me Yesterday," was a coy account of an acid trip. Its parody of a policeman and a voice asking "What kind of joint is this?" acquired a different meaning when Redlands was raided three weeks after its release, but the bust did not silence them. Jagger explained the mind-expanding properties of LSD on one BBC show that spring (The Look of the Week) and Faithfull declared the drug to be (quoted in Faithfull and Dalton 97) that LSD was "[m]ore important" than Christianity on another.

Richards later credited the Redlands trial for establishing him as the archetypal rock and roll outlaw. "The judge managed to turn me into some folk hero overnight," he recalled: "I've been playing up to it ever since" (quoted in Richards and Fox 227). Drug-taking was to become an intrinsic element of the Stones' rebel brand, but in 1967 it seemed more likely to end their careers. Their manager was an addict whose response to the bust was to flee the country. Drugs rendered Jones increasingly incapable of touring or recording. The band was ill-prepared to survive the incarceration of their two songwriters and their post-trial releases sold poorly by their standards. The marketing potential of drug use was hard to discern at a 
time when opinion polls indicated that almost no one had taken illicit drugs and almost everyone was opposed to them (Gallup 934).

The unintended consequences for The News of the World began when the article which sparked the Redlands Affair confused cannabis with acid and Jagger with Jones. The paper sought to prove Jagger's drug-taking in order to quash the libel case, teach him a lesson and achieve vindication in the eyes of its readership. Instead, the Redlands Affair escalated into a cause celèbre in which its journalists faced as many accusations as the convicted criminals. The Stones made the mistaken but widely believed allegation that The News of the World had set them up by planting Schneidermann at the party together with his cornucopia of drugs. The highbrow papers accused it of creating the news rather than just reporting it: a charge which could just as easily been levelled against The Times' intervention into an ongoing criminal case. But the most unintended consequence of The News of the World's actions was that they revealed the drug problem at the cost of publicizing and glamorizing it, paradoxically encouraging the very phenomenon they sought to suppress. A scare story published in 1967 about the "The Heaven and Hell Drug" prompted one group of hippies to ask themselves "Where can we get some of this heaven and hell shit?" (Dave Goodman quoted in Green 175-6).

The drug laws were similarly counterproductive in being at once repressive and ineffective. Fraser had been caught red-handed with heroin jacks, but his behavior was criminalized only because he lacked a prescription for them. Furthermore, the appeals court claimed in an act of pure casuistry that he was not being jailed for possession of the drugs on his person — as an addict, he was impelled to satisfy his cravings — but for having started on the road to addiction by taking his first hit.

Jagger's conviction revealed any number of problems with the law. The first was the difficulty in establishing possession, since the amphetamine tablets were not actually his but 
Faithfull's. The second was the unreliability of experts intended to perform a paternalistic function. A Harley St. doctor swore under oath that he gave Jagger verbal permission to use the drugs. Yet this is doubtful to say the least, given that the pills belonged to Faithfull and that amphetamine use by the Stones' circle was no one-off event. The third problem was that the custodial sentence imposed on Jagger exposed the inadequacy of legislation which made no distinction between users and dealers and too absolute a distinction between use of the same drugs with and without a prescription. Jagger was jailed for the unauthorized possession of four amphetamines that were prescribed in their millions alongside the benzodiazepines satirized in "Mother's Little Helper."

Whereas Mick Jagger was convicted of a crime he didn't commit, Keith Richards was eventually acquitted for a crime he had committed: that of allowing his premises to be used for the smoking of cannabis. This was because that the prosecution had to prove that the general air of abandon at Redlands was a result of cannabis use when it could just as easily have caused by drinking and was in fact due largely to the house party having taken acid en masse, an offence for which no one was charged. The prosecution rested its case on the high spirits and state of undress of Faithfull, who had briefly revealed all to a policewoman. Prosecutors were supported in their endeavor by the press, which ran concurrent stories about Faithfull's determination to live in sin with Jagger; and by the rumor mill, which fantasized about police catching Jagger in the act of consuming a Mars Bar lodged in Faithfull's vagina. Fraser's prior conviction under the Vagrancy Act for having exhibited explicit paintings by Jim Dine provided a further link to obscenity.

In other words, an entire permissive lifestyle was put on trial, with drugs, cohabitation, exhibitionism, and cunnilingus all presented as forming parts of a licentious whole. While legally prejudicial, the prosecution's depiction of the Stones' milieu was not far off the mark. Those present at the house party that day represented moral crusader Mary 
Whitehouse's worst nightmare. In addition to Jagger, Faithfull, and Richards, the guests consisted of a Californian "Acid King," a depressive photographer, a North African houseboy whose duties extended to the sexual, a man so camp as to be mistaken for a woman by the police, an art dealer who exhibited obscene pictures and failed to pay his bills, and a hangeron whose only claim to fame was to have fed acid to a rabbit he had dyed green (Barry Miles quoted in Décharné 202-3). Three of the party were gay and two were bisexual. All save the designated driver had been "gibbering with acid" earlier in the day (Christopher Gibbs quoted in Richards and Fox 250) and half either were heroin addicts or were shortly to become so. It was therefore unsurprising if unwise for Richards to rise to the prosecution's bait by defending Faithfull's nudity as entirely normal and natural. "We are not old men," he declared: "We are not worried about petty morals," thereby scuppering his lawyers' attempts to portray the accused as responsible, respectable citizens (quoted in "Keith Richard Says" 2).

The Affair revealed decided less permissive attitudes towards women: a thorny issue for the Stones (August). During the Affair, Marianne Faithfull allowed Jagger to shield her from prosecution by claiming her pills as his own. Yet she soon realized that Jagger's chivalry and the anonymity accorded to her in court proceedings rendered her passive, silenced and subject to lurid sexual slanders. Although Jagger's barrister objected that "Miss X.” had no opportunity to refute her portrayal as a "drug-taking nymphomaniac" (Michael Havers quoted in “Stone's QC"), he strove with Jagger to prevent her from taking the stand. "The Woman, you see, is not meant to say anything," she explained in Faithfull, one of the first feminist memoirs by a popular musician:

Of course, I might have gone to jail, but ... [i]nstead of doing my Joan of Arc bit I was stuck for years with this ridiculous rock-star-moll image. Or worse, the helpless little victim of the big bad rock stars! (110) 
She blamed the same double standard for turning Jagger and Richards into "glamorous outlaws" for their drug use, whereas her reputation was "destroyed by the very things that enhanced them" (quoted in McDonnell).

The final set of actors in this tragicomedy were liberal commentators, who superficially appeared to accomplish their objectives in the Redlands Affair. They portrayed the prosecution as a form of persecution which would turn the generation gap into a chasm. Liberals also claimed that the exemplary sentences ran counter to the customary impartiality and moderation of British justice. Such was the gist of the celebrated Times editorial penned by William Rees-Mogg entitled "Who Breaks A Butterfly on a Wheel?" (11). Rees-Mogg sought to uphold what he termed "sound traditional values" such as tolerance, proportionality, judicial independence, and equality before the law (Rees-Mogg, "Who" 11). His conviction that Jagger had been incarcerated for the pettiest of crimes prompted him to chair the World In Action debate and authorize the publication in The Times of an advertisement (3) critiquing the "immoral and ... unworkable" laws on cannabis placed by the pressure group Soma.

Yet liberals were mistaken to believe that the Stones enjoyed the support of their generation. Two polls indicated that only a minority of the young considered the three-month sentence on Jagger "too severe." Just 12\% of 21-34 year-olds said as much to NOP in July (Longmuir 1), although that figure climbed to $25 \%$ of $18-20$ year-olds in a Gallup poll (Gallup Political Index 130) conducted immediately after the appeals court ruling three weeks later. The likes of Cliff Richard demonstrated their ability to speak for the mainstream as well as sing to it when denouncing the Stones' drug use (Richard). Moreover, ReesMogg's campaign to prevent one miscarriage of justice unwittingly helped to facilitate another. The Stones got away with committing offences in an attempted cover-up which 
dwarfed those for which they were charged, sanctioning policemen to be bribed and alleged informers to be assaulted (Richards and Fox 208).

Miscalculations therefore drove the Redlands Affair from start to finish. The News of the World denounced the wrong Stone for taking the wrong drug. Jagger's attempts to suppress all mention of his drug-taking provoked the most famous bust of the era. The raid itself was "a major cock-up," as one policeman admitted, since officers failed to find what they were looking for and "didn't know what to charge them [the Stones] with" (Don Rambridge quoted in Vyner 180). Furthermore, the trial exposed the new drug laws to be unfit for purpose in one of their first major tests, with chairman of the magistrates Judge Block imposing excessive sentences for insecure convictions on unreliable evidence.

This was clearly not a process directed by anybody, permissive or anti-permissive, but a process was occurring nonetheless. As journalist Tim Hewat noted (6), the Redlands Affair "led to a discussion of questions and social situations which until then most of Britain preferred not to think about." The Affair turned drug-taking among popular musicians into a test case of the nature, effects, and desirability of permissiveness in sixties Britain. The ensuing debate was as inconclusive as the trial itself, yet the manifest lack of consensus among its participants over the issues of drugs, sexuality, individual liberty, and social responsibility demonstrated that Britain was becoming a more pluralistic nation in which diverse groups practiced and preached rival lifestyles and moral codes. In this respect, the sixties constituted 'a period that fractured established moral orthodoxies' (Mort, "Permissive Society” 296) to a degree not fully acknowledged in recent skeptical accounts.

\section{Fissiparous permissiveness}

The jailing and subsequent freeing of Jagger and Richards initially seemed to act as a catalyst for a campaign to reform the drug laws along the lines of other permissive legislation. Rees- 
Mogg found Jagger apparently willing to act as an interlocutor between the counterculture and the establishment and between the young and the old, leading to their memorable meeting on World in Action. Jagger flirted with Labour MP Tom Driberg's suggestion that he stand for parliament (Wheen 359-60) and appealed to liberal consciences by comparing the laws against drugs with those against homosexuality when assuming the role of Oscar Wilde in the promotional film for the "We Love You" single. The promo was recorded on 30 July, the day before their appeal and three days after royal assent was granted to the Sexual Offences Act decriminalizing male homosexuality.

The Redlands Affair also prompted the hitherto oppositional counterculture to engage in pressure group activity. The Times ended its foot-dragging over publishing the Soma ad and Soma's founder, Steve Abrams (quoted in Plinston 17), found himself "dealing directly with ... the medical and political sides of the establishment." Two MPs signed the Soma ad and another, Paul Channon, was briefed by Abrams for an adjournment debate on soft drugs in July. That summer also spawned the charity Release, which provided legal support to those arrested for drugs offenses, after Caroline Coon and Rufus Harris met at a demonstration against the jailing of Jagger and Richards (Coon; Mold, "Welfare Branch"). Hippies staged a Legalize Pot Rally in the most traditional of protest venues, Hyde Park, and $O z$ urged its readers to complain to the Press Commission about irresponsible newspaper coverage ("How I Jailed Jagger").

Many of the conditions for permissive reform had therefore been met in reaction to the Redlands trial. Pressure groups became active, journalistic crusades were launched and a dialogue was initiated between Establishment figures and articulate representatives of minority groups. Yet this alliance between liberals, the Stones, and the counterculture did not last due to the incompatible agendas and strategies of its constituent elements. 
Liberals were mollified by the Appeals Court ruling which overturned Richards' conviction and commuted Jagger's to a suspended sentence. Their faith in the self-correcting nature of British justice had been restored, though they had not been exactly alienated to begin with. It was significant that Rees-Mogg's celebrated editorial failed to defend Fraser, Richards or Schneidermann and questioned the severity of the sentence against Jagger rather than the rectitude of the law per se. It was unreasonable to expect a libertarian stance from a Catholic moralist who lamented the rise in "delinquency, drug-taking ... suicide [and] promiscuity" in his religious tracts (Rees-Mogg, Humbler Heaven 66). Times editorials later that year denounced "fallacious" claims made in the Soma ad, declared that "The Times is not in favour of legalizing cannabis" ("Right to Dissent" 9), and suggested that mind-expansion was best left to religious mystics (“Blessing In Shades Of Green” 11).

Rees-Mogg's fundamentally paternalistic approach accounted for his patronizing metaphor of protecting that most ephemeral and defenseless of creatures, the butterfly. But Jagger was no butterfly; still less was he "a Thatcherite before Thatcherism," as Rees-Mogg would later claim (Rees-Mogg, Memoirs 160). Jagger's eye-catching discussions with Establishment figures belied the manner in which the Affair compounded his alienation from state and society. Having experienced his nights in jail as the antithesis of permissiveness, he denounced Britain as "a police state" (quoted in Buckle 381), its politicians as besuited hawkers and its parties as offering a choice between "polio and cancer" (quoted in Sandford 238). He depicted the court proceedings as a "game" conducted by "horrible grey people" (quoted in Miles 22) and hostile members of the public as "mindless" (quoted in Jessell 8) and envious of his financial and sexual success. While Rees-Mogg (quoted in Whitworth 8) correctly saw Jagger as "basing his arguments [in the World In Action debate] on those which had been used by John Stuart Mill in On Liberty," within a matter of weeks Jagger's libertarianism had evolved into a self-declared anarchism according to which "There should 
be no such thing as private property" (quoted in Crump; see Doggett for the radicalization of sixties musicians).

The Stones were essentially too unrespectable, unrepresentative, and uninterested to forge a viable allies with liberals. The lyrics for "We Love You" drew battle lines between supporters ("we") and adversaries ("you") which it addressed in a hectoring, scornful, defiant, and triumphant manner, and its banned promo film demonstrated that the Stones still associated permissiveness with provocation. It depicted them parodying flower power and flirting with homosexuality, androgyny, and nudity. It advanced a conspiracy theory in which the courts were in league with the press (the judge's wig being fashioned out of rolled-up newspapers) and paraded the Stones' drug use by showing Brian Jones in a thoroughly wasted state. Their Satanic Majesties Request, mostly recorded in the month between Jagger and Richards' sentencing and appeals, placed further distance between the band and potential liberal allies. The Stones stoked the fires of controversy by aligning themselves with Satan instead of Britain in the album title and evoking drug experiences on the record through ethereal sounds, exotic instrumentation, snippets of speech ("Where's that joint?") and lyrical allusions (see Whiteley ch. 5). A central reference point was The Beatles' dreamlike "Lucy in the Sky with Diamonds," released a month before the main Satanic Majesties sessions. "Lucy"'s river and fountain flow into "Gomper"'s lake and its 'tangerine trees' turn blue in "In Another Land," where the grass grows as high as Lennon's flowers.

The unrepresentativeness of the Stones and their circle was revealed by an NOP poll (Longmuir 1), which indicated that a majority of adults thought Jagger's sentence to be "not severe enough." Not that the Stones much cared what ordinary people thought. Jagger's lyrics for "Salt of the Earth" (1968) advanced his belief (quoted in Oberbeck 47) that "those people haven't any power and they never will have," while Faithfull likened the British bobbies descending upon Redlands to the troglodytes featuring in H.G. Wells' The Time Machine 
(quoted in Faithfull and Dalton 108). The Stones' elitism and estrangement from society made them less interested in changing legislation than in gaining immunity from it. Jagger thought the drug laws insufficiently "important" for him to campaign against (quoted in Connolly), even if his efforts served to "speed up the process of reform by perhaps ten years." Richards reportedly commissioned a nine-foot high brick wall to be erected around his Redlands property (Greville). The Stones seldom championed permissive causes except out of self-interest, as when the Beggars Banquet cover was censored in 1968.

Pressure group activity by the counterculture did not betoken respectability. Soma's attempt to distinguish between cannabis and other drugs was undermined by its most celebrated sponsors being the Beatles, whose use of LSD had just come to light and whose manager Brian Epstein died of a drug overdose a month after signing the petition. Release's Abrams and Coon confirmed their unrespectability by being fined for a breach of the peace later in 1967 following the conviction of the hapless Brian Jones ("Six Demonstrators" 11). Jim Callaghan discredited the Wootton Committee's recommendations for drug reform in 1969 by suggesting that that Soma had influenced its findings.

Yet Soma and Release were still much too respectable for many in the counterculture, who treated the groups' leaders with suspicion and disdain. Alternative countercultural strategies ranged from Mick Farren's fantasies ("Sub-Ed" 2) about "stomp[ing] the first cop I meet" to an all-too-literal interpretation of flower power in the form of a plan to inundate the Redlands trial judge with innumerable bouquets (Wyman and Coleman 445). The Affair confirmed most counterculturalists in their oppositional stance against "the bad guys" in government and the narcotics police (Joe Boyd quoted in Green 127). They dismissed unwelcome opinion poll data as so much "propaganda" and "nonsense" (Wilcock 16), labeled MPs as "scum" and "farts" ("An Address" 13), and denounced "the money-grubbing, witchhunting, God-playing fascism" of The News of the World (“How I Jailed Jagger"). 
This Manichaean stance obscured the fact that the counterculture was morally compromised and unfit to govern itself. Scamming, freeloading, and petty pilfering were rife in the Underground and drugs destroyed several of its leading lights. The editor of its parish magazine, Tom McGrath, was a junkie and the leader of its house band, Syd Barrett of Pink Floyd, an acid casualty. The more thoughtful members of the counterculture, including McGrath ("The H Problem" 2) and Donovan in his liner notes to A Gift from a Flower to the Garden (1967), hoped that experimentation with drugs would exhaust itself, much as the state would wither away under Marxism. In both cases the opposite occurred.

A coalition for reform of the drug laws was unsustainable in the 1960s because the aims and methods of its potential members were irreconcilable. Moreover, their irreconcilability indicates that permissive causes could be not merely distinct but conflicting. Two rival conceptions of permissiveness clashed in the Redlands Affair, with journalists' freedom to expose illegality pitted against the freedom of the Stones and their circle to undertake consensual acts in private. The hippies who marched on Fleet Street on the day that Jagger and Richards were jailed saw no contradiction in their twin demands of "Freeing the fucking Stones, and closing down the fucking News of the World!" (quoted in Farren, Give The Anarchist).

The diverse strands within permissiveness on display in the Affair help to explain why MPs championing particular permissive causes often opposed others. Norman St JohnStevas sponsored reform of the laws on censorship and male homosexuality but argued against those for abortion and divorce. Leo Abse shared St John-Stevas' attitudes to abortion and homosexuality but differed with him on divorce. Kenneth Robinson agreed with the two of them on male homosexuality, disagreed on abortion and campaigned to tighten the law on amphetamines. Ronald Bell voted to abolish the death penalty and was one of the very few MPs to object to repressive drug laws, while being in other respects a fully paid-up member 
of the arch-reactionary Monday Club. The lines between permissives and anti-permissives did exist in 1960s Britain, but they were easily crossed.

\section{Conclusion}

The Redlands Affair raises fundamental questions about the nature and extent of the “permissive society" in 1960s Britain. The countercultural newspaper $O z$ argued at the time (“How I Jailed Jagger") that "vicious exemplary punishments" were inflicted on the defendants precisely because "the Stones symbolise the new permissiveness." So was the Affair indicative of the rise of permissiveness, or anti-permissiveness, or both, or neither? Partial answers have been provided by the four principal models of permissivenessconservative, radical, liberal, and skeptical —in half a century of commentary and scholarship on the Redlands Affair. The conservative moralists' portrayal of a "middle-aged establishment" capitulating to the "immoral force" of rock music is overwrought and incorrect (Hitchens, Brief 218). The only politicians publicly defending the Stones in 1967 were Driberg and fellow maverick Lord Moynihan, and the debate on the Wootton Report two years later found "the two Front Benches united as seldom before in total condemnation of any moves towards a more lenient attitude to drugs" (Noyes 1). Conservatives' favorite scapegoat for moral decline, Home Secretary Roy Jenkins, authorized the outlawing of LSD, endorsed the Brain committee's restrictions on prescribing narcotics and defended the handcuffing of Jagger and Fraser. There was no mention of drug users in Jenkins' vision of a permissive "civilized society" (quoted in Campbell 299).

Whereas conservatives claim that "Britain's governing classes deliberately missed th[e] opportunity" (Hitchens, Brief 218) to arrest the spread of recreational drugs, radical accounts portray the Affair as part of an establishment clampdown on alternative lifestyles. Richards' and Faithfull's autobiographies advance conspiracy theories according to which 
they were subject to '[p]unishment for everything, for being different, having fun, being young" by the forces of conservatism (quoted in Faithfull and Dalton 113). Their claims are not only factually inaccurate, as when Faithfull alleges that the authorities "must have flown him [Schneidermann] in for this bust" (quoted in Faithfull and Dalton 101) when he was in fact on the run. They are also internally contradictory. Richards detects collusion in the police's failure to open Schneidermann's drug-stuffed briefcase but attributes their inability to discover drugs stuffed down the sofa to sheer incompetence. No plausible reason appears in his account (quoted in Richards and Fox 229) for why the Establishment switched from persecuting the Stones to "trying to make peace with us, like [Neville] Chamberlain." Sandbrook's explanation that "there was no such thing a single, united Establishment" (524) does not seem to have occurred to him. Richards is aware, however, that the Redlands Affair failed to demonize him in accordance with classic CCCS accounts of moral panic. His elevation from folk devil to folk hero corroborates Sarah Thornton's contention (6) that moral panics "often have the effect of certifying transgression and legitimizing youth cultures."

Abrams observes how liberals overstated their own importance in the Redlands Affair by claiming, for example, that The Times' editorial secured the release of Jagger when he been freed the previous day (45). "Measured judgement" is difficult to discern among the politicians who enacted flawed drug legislation. It was rare too among those enforcing the law, as various members of the police and judiciary countermanded each other. In truth, the authorities and the press had little control over the situation. The ineffectiveness of the most stringent of laws showed that permissiveness required no government fiat. Sanctioned or not, recreational drug use was here to stay.

David Fowler's recent reworking of the liberal model does not withstand scrutiny. While he makes effective use of government records to challenge radical claims of an allencompassing establishment conspiracy, his assertion that the Affair made Jagger "the 
youngest member of the British cultural establishment" (180) rests on a number of mistaken assumptions. The Stones did not receive the backing of "most of the Fleet Street journalists who wrote about the trial" (186), and those who did were lampooned for their pains (see Pitman; "Editorial"). Nor is there any evidence that "the middle classes of the Home Counties" came to regard Jagger with "undoubted respect" during the Affair (180). The poll he cites shows that just $19 \%$ of upper-middle-class respondents thought that Jagger had been unfairly treated by the courts (Longmuir 1). Moreover, Fowler's contention that Jagger was "in no sense an anti-adult youth rebel" (187) is hard to reconcile with many statements to the contrary, such as when Jagger pronounced that "Older people are frightened of young people 'cause they're frightened of freedom. They [the old and the young] are not a bit alike" (quoted in Francis).

The visceral anti-authoritarianism of the Stones and their supporters argues against interpretations which question the significance of the Redlands Affair and, by extension, the radicalism of the Underground. The counterculture lived up to its name by seeking alternative ways of living and thinking. It developed its own worldview, moral code, argot, institutions, and networks. Drugs and popular music were integral to the scene, which is why the Redlands Affair galvanized the counterculture as never before. We should be careful not to let Underground heroes dominate our depictions of the sixties, for they were estranged from the society in which they lived. Conversely, scholars should not consider themselves to be "distracted" (Mills 116) by celebrities such as the Stones, whose misadventures did as much as anything else in the decade to raise public awareness of recreational drug use.

This article has emphasized the provisional nature of permissiveness in sixties Britain, showing it to be on trial in every sense of the word. The Redlands Affair represented to its principal participants - politicians, the press, the Stones, the courts, and the counterculture - a prime opportunity to establish what was and was not permissible in the sixties. Some were 
exploring new possibilities, others were determined to establish limits, but all were engaged in a trial-and-error process of finding out where the boundaries lay.

The Affair, though ostensibly a showdown between permissive and anti-permissive forces, demonstrated that permissiveness was not one package to be embraced or rejected. Permissiveness is better understood as a constellation of behaviors and beliefs championed by different interest groups and ideological groupings. The Stones interpreted permissiveness as the right to behave badly. The less confrontational members of the counterculture wished to govern themselves. The newspapers were fundamentally interested in furthering their own freedom of expression. The Times wished to challenge cases on appeal, while The News of the World wished to delve into celebrities' private lives. "How do you measure permissiveness?" mused Mick Jagger in 1987 (quoted in Turner). The Redlands Affair revealed the question to be at once vital and unresolved in 1960s Britain. The definition of permissiveness was disputed, its scope contested, its worth questioned, and its future decidedly uncertain.

“An Address to Politicians." $O z 3$ (March-April 1967): 13. Print.

"Blessing in Shades of Green.” The Times 15 July 1967: 11. Print.

“Editorial.” Private Eye 183 (10 December 1968): 5. Print.

“How I Jailed Jagger.” Oz Sheet 1 (May 1967). Print.

“Interview with Paul McCartney”. ITN, 19 June 1967: 〈https://youtu.be/Y4CRTTr4UcE> “Keith Richard Says Nude Girl Came Down from Bath.” The Times 30 June 1967: 2. Print. “Mick Jagger.” Melody Maker 30 January 1965: 9. Print.

“New Drug For Short 'Trips'.” The Times 15 August 1967: 5. Print.

“Six Demonstrators to Pay 60 gns Costs." The Times 22 December 1967: 11. Print. 
“Speed of Increase in Drugs Problem Worries Mr Howell." The Guardian 1 June 1968: 2. Print.

“Stone's QC Defends the 'Merry Nude in a Slipping Rug." Daily Mail 29 June 1967: 7. Print. “The Right To Dissent.” The Times 23 October 1967: 9. Print.

"You." IT 1.1 (October 1966): 8. Print.

Abrams, Steve. "Soma, the Wootton Report and Cannabis Law Reform in Britain during the 1960s and 1970s'. A Cannabis Reader: Global Issues and Local Experiences. Ed. Sharon Rödner Sznitman, Börje Olsson, and Robin Room. Lisbon: European Monitoring Centre for Drugs and Drug Addiction, 2008. 29-49. Print.

Addison, Paul. No Turning Back: The Peaceful Revolutions of Postwar Britain. Oxford: Oxford University Press, 2010. Print.

Altham, Keith. “The Rolling Stones: Our Fans Have Moved On With Us.” New Musical Express 4 February 1967. <https://www.rocksbackpages.com/Library/Article/the-rollingstones-our-fans-have-moved-on-with-us> August, Andrew. "Gender and 1960s Youth Culture: The Rolling Stones and the New Woman.” Contemporary British History 23.1 (2009): 79-100. Print.

Bacon, Alice. Parliamentary Debates (Commons), 751 (28 July 1967). <http://hansard.millbanksystems.com/commons/1967/jul/28/soft-drugs> Barnes, Tim. "Loosen Up: The Rolling Stones Ring in the 1960s.” Living Through Pop. Ed. Andrew Blake. London: Routledge, 1999. Print.

Bingham, Adrian. Family Newspapers? Sex, Private Life, and the British Popular Press, 1918-1978. Oxford: Oxford University Press, 2009. Print.

Bloom, Allan. The Closing of the American Mind. New York: Simon and Schuster, 1987. Print. 
Bokris, Victor. Keith Richards: The Unauthorised Biography. London: Hutchinson, 1992. Print.

Braine, Bernard. Parliamentary Debates (Commons), 744 (6 April 1967).

<http://hansard.millbanksystems.com/commons/1967/apr/06/dangerous-drugs-bill>

Bromell, Nick. Tomorrow Never Knows: Rock and Psychedelics in the 1960s. Chicago:

University of Chicago Press, 2000. Print.

Brooke, Henry. Parliamentary Debates (Commons), 697 (23 June 1964).

<http://hansard.millbanksystems.com/commons/1964/jun/23/malicious-damage-bill>

Brooke, Stephen. Sexual Politics: Sexuality, Family Planning and the British Left from the 1880s to the Present Day. Oxford: Oxford University Press, 2011. Print.

Buckle, Richard, ed. Self Portrait with Friends: The Selected Diaries of Cecil Beaton, 19261974. London: Littlehampton, 1979. Print.

Callaghan, James. Parliamentary Debates (Commons), 776 (27 January 1969).

<http://hansard.millbanksystems.com/commons/1969/jan/27/cannabis-wootton-report>

Campbell, John. Roy Jenkins: A Well-rounded Life. London: Jonathan Cape, 2014. Print.

Cloonan, Martin. Banned! Censorship of Popular Music in Britain, 1967-92. Aldershot: Arena, 1996.

Coates, Norma. "If Anything, Blame Woodstock: The Rolling Stones - Altamont, December 6, 1969.” The Performance of Popular Music: History, Place and Time. Ed. Ian Inglis. Aldershot: Ashgate, 2006. 50-69. Print.

Collins, Marcus, ed. The Permissive Society and Its Enemies: Sixties British Culture. London: Rivers Oram, 2007. Print.

Collins, Marcus. "I Feel Free: The Worldview of British Rock and Pop Musicians, c. 19651975." Popular Culture in Britain and America, 1950-1975. Cheltenham: Adam Matthew 


\section{Digital, 2013.}

<http://www.rockandroll.amdigital.co.uk/FurtherResources/Essay/MarcusCollins.aspx>

Collins, Marcus. "Sucking in the Seventies? The Rolling Stones and the Aftermath of the Permissive Society.” Popular Music History 7.1 (2012): 5-23. Print.

Connolly, Ray. “Mick Jagger.” 1967.

<http://www.rayconnolly.co.uk/pages/journalism_01/journalism_01_item.asp?journalism_01 $\mathrm{ID}=22>$

Coon, Caroline. "We were the Welfare Branch of the Alternative Society." The Unsung Sixties: Memoirs of Social Innovation. Ed. Helene Curtis and Mimi Sanderson. London: Whiting and Birch, 2004. 183-197. Print.

Crump, John (aka J.C.), “Politics of Pop.” Socialist Standard (February 1968).

<http://www.worldsocialism.org/spgb/centenary/pop(1968).pdf>

Dalton, David and Mick Farren, ed. The Rolling Stones: In Their Own Words. London: Omnibus, 1980. Print.

Davies, Christie. The Strange Death of Moral Britain. New Brunswick, NJ: Transaction, 2006. Print.

Davis, John. "The London Drug Scene and the Making of Drug Policy, 1965-73.”

Twentieth-Century British History 17.1 (2006): 26-49. Print.

Davis, Stephen. Old Gods Almost Dead: The 40-Year Odyssey of the Rolling Stones. New York: Broadway, 2001. Print.

Décharné, Max. King's Road: The Rise and Fall of the Hippest Street in the World. London: Phoenix, 2006. Print.

DeRogatis, Jim. Kaleidoscope Eyes: Psychedelic Rock from the 60s to the 90s. Secaucus, NJ: Carol Publishing, 1996. Print. 
Dick, Luke and George A. Reisch, ed. The Rolling Stones and Philosophy: It's Just A Thought Away. Chicago, IL: Open Court, 2012. Print.

Doggett, Peter. There's A Riot Going On: Revolutionaries, Rock Stars and the Rise and Fall of 60s Counterculture. Edinburgh: Canongate, 2007. Print.

Dorn, Nick. "The Conservatism of the Cannabis Debate: Its Place in the Reproduction of the 'Drug Problem'.” Permissiveness and Control: The Fate of the Sixties Legislation. Ed.

National Deviancy Conference. London: Macmillan, 1980. Print.

Drug Addiction: Report of the Interdepartmental Committee. London: HMSO, 1961. Print. Drug Addiction: Report of the Second Interdepartmental Committee. London: HMSO, 1965. Print.

Faithfull, Marianne and David Dalton. Faithfull. London: Little, Brown, 1994. Print. Farber, David. "The Toxicated State and Illegal Nation: Drugs in the Sixties Counterculture." Imagine Nation: The American Counterculture of the 1960s and 1970s. Ed. Peter Braunstein and Michael William Doyle. London: Routledge, 2002. 17-40. Print.

Farren, Mick. "Sub-Ed.” IT 1.15 (June 1967): 2. Print.

Farren, Mick. Give the Anarchist a Cigarette. London: Vintage Digital, 2010. Ebook. Faulk, Barry. British Rock Modernism, 1967-1977: The Story of Music Hall in Rock. Aldershot: Ashgate, 2010. Print.

Fowler, David. Youth Culture in Modern Britain, 1920-1970. Basingstoke: Palgrave, 2008. Print.

Francis, Miller Jr. "The Blues.” The Great Speckled Bird 2.14 (1969): 9. Print. Furlong, Monica. "The Shallow Idols of Society and the Smell of Decadence." Daily Mail 30 June 1967: 6. Print.

Gallup Political Index 88 (1967). Print. 
Green, Jonathon. Days in the Life: Voices from the English Underground, 1961-1971. London: Minerva, 1989. Print.

Greenfield, Robert. “Keith Richard: The Rolling Stone Interview.” Rolling Stone 19 August 1971. <http://www.rollingstone.com/music/news/keith-richards-the-rolling-stone-interview19710819>

Greenwood, Victoria and Jock Young, "Ghettos of Freedom: An Examination of Permissiveness." Permissiveness and Control: The Fate of the Sixties Legislation. Ed. National Deviancy Conference. London: Macmillan, 1980. Print.

Greville, Charles. “How high is a Stone’s wall?” Daily Mail 28 July 1967: 4. Print.

Hall, Stuart et al. 1978. Policing The Crisis: Mugging, the State and Law and Order.

Basingstoke: Macmillan. Print.

Harrison, Brian. Seeking A Role: The United Kingdom, 1951-1970. Oxford: Oxford University Press, 2009. Print.

Harron, Mary. "McRock: Pop as a Commodity." Facing the Music: A Pantheon Guide to Popular Culture. Ed. Simon Frith. London: Mandarin, 1990: 173-220. Print.

Hewat, Tim. The Rolling Stones File. London: Panther, 1967. Print.

Hitchens, Peter. A Brief History of Crime (London: Atlantic, 2003). Print.

Hitchens, Peter. The War We Never Fought: The British Establishment's Surrender to Drugs. London: Bloomsbury, 2012. Print.

Jarvis, Mark. Conservative Governments, Morality and Social Change in Affluent Britain, 1957-64. Manchester: Manchester University Press, 2005. Print. Jessel, Stephen. “Mr Mick Jagger Speaks His Mind.” The Times 1 August 1967: 8. Print. Jones, Tim and Christopher Warman. “'Stones' - Protest at 2am.” The Times 1 July 1967: 1. Print. 
Kohn, Marek. Dope Girls: The Birth of the British Drug Underground. London: Lawrence and Wishart, 1992. Print.

Loder, Kurt. "Keith Richards: The 40 Anniversary Interview.” Rolling Stone (3 May 2007): <http://www.rollingstone.com/music/news/keith-richards-the-40th-anniversary-interview20070503>

Logan, Nick. “Today's 'More Peaceful': Keith Richard Looks Ahead to Touring Again." New Musical Express 9 August 1969: 4. Print.

Longmuir, Harry. “Jagger: Not Tough Enough.” Daily Mail 14 July 1967: 1-2. Print. Lynskey, Dorian. “Rock’s Fake Rebels.” The Observer 17 October 2010. <https://www.theguardian.com/global/2010/oct/17/keith-richards-sexism-rolling-stones> MacDonald, Ian. The People's Music. London: Pimlico, 2003. Print. Macleod, Iain. Parliamentary Debates (Commons), 756 (21 December 1967). <http://hansard.millbanksystems.com/commons/1967/dec/21/crude-spirit-drinkers-treatment> Mann, Manfred. "Controls on Drug Taking.” The Times 1 April 1967: 11. Print. Marwick, Arthur. British Society since 1945. Harmondsworth: Penguin, 1982. Print. Marwick, Arthur. The Sixties: Cultural Revolution in Britain, France, Italy and the United States, c. 1958-74. Oxford: Oxford University Press, 1998. Print.

McDonnell, Evelyn. “Marianne Faithfull.” Interview April 2009.

<http://www.rocksbackpages.com/Library/Article/marianne-faithfull-4>

McGrath, Tom. "Bust.” IT 1.10 (March 1967): 1, 3-4. Print.

McGrath, Tom. “The H Problem.” IT 1.9 (February 1967): 2. Print.

McMillian, John. Beatles vs. Stones. New York, NY: Simon \& Schuster, 2013. Print.

Melly, George. Revolt Into Style: The Pop Arts in Britain. London: Allen Lane, 1970. Print. Miles, ed. Mick Jagger in His Own Words. London: Omnibus, 1982. Print. 
Mills, James H. Cannabis Nation: Control and Consumption in Britain, 1928-2008. Oxford: Oxford University Press, 2012. Print.

Mitchell, Adrian. “Adrian Mitchell's Guide to the Underground." The Permissive Society: The Guardian Inquiry. Ed. Harford Thomas. London: Panther, 1969. 39-46. Print.

Mold, Alex. “"The Welfare Branch of the Alternative Society?' The Work of Drug Voluntary Organization Release, 1967-1978." Twentieth-century British History 17.1 (2006): 50-73. Print.

Mold, Alex. Heroin: The Treatment of Addiction in Twentieth-century Britain. De Kalb, IL: Northern Illinois University Press, 2008. Print.

Mort, Frank. “The Permissive Society Revisited.” Twentieth-century British History 22.2 (2011): 269-298. Print.

Mort, Frank. Capital Affairs: London and the Making of the Permissive Society. New Haven, CT: Yale University Press, 2010. Print.

National Deviancy Conference, ed. Permissiveness and Control: The Fate of the Sixties Legislation. London: Macmillan, 1980. Print.

Newburn, Tim. Permission and Regulation: Law and Morals in Postwar Britain. London: Routledge, 1992. Print.

Nik Cohn. Awopbopaloobop Alopbamboom: The Golden Age of Rock. London: Minerva, 1969. Print.

Noyes, Hugh. “MPs Unite to Crush ‘Pro Pot Lobby'.” The Times 28 January 1969: 1. Print. Nuttall, Jeff. "Letter.” IT 1.10 (March 1967): 2. Print.

Oberbeck, S.K. "Mick Jagger and the Future of Rock.” Newsweek 4 January 1971: 47. Print. Paytress, Mark. The Rolling Stones Off The Record: Outrageous Opinions and Unrehearsed Interviews. London: Omnibus, 2003. Print.

Pitman, Robert. “In My Opinion.” Daily Express 2 August 1967: 6. Print. 
Plinston, Graham. "Steve Abrams.” IT 1.22 (December 1967): 16-17. Print.

Rees-Mogg, William. “Who Breaks a Butterfly on a Wheel?” The Times 1 July 1967: 11. Print.

Rees-Mogg, William. 2011. Memoirs. London: HarperPress. Print.

Rees-Mogg, William. An Humbler Heaven: The Beginnings of Hope. London: Hamish Hamilton, 1977. Print.

Richard, Cliff. "Why I Disagree with Mick Jagger" (2 August 1967). 50 Years - The Rolling Stones, part 1: Views from The Inside, Views from The Outside. Ed. Hanspeter Künzler. Zürich: eBook People. Ebook.

Richards, Keith and James Fox. Life. London: Weidenfeld and Nicolson, 2010. Print. Roberts, Andy. Albion Dreaming: A Popular History of LSD in Britain. London: Marshall Cavendish, 2008. Print.

Sandbrook, Dominic. White Heat: A History of Britain in the Swinging Sixties. London: Little Brown, 2006. Print.

Sandford, Christopher. Mick Jagger: Primitive Cool. London, Gollancz, 1993. Print.

Sandford, Christopher. Mick Jagger: Primitive Cool. London: Gollancz, 1993. Print. Shapiro, Harry. Waiting for the Man: The Story of Drugs and Popular Music. 2nd ed. London: Helter Skelter, 1999. Print.

Soma. "The Law against Marijuana is Immoral in Principal and Unworkable in Practice.” The Times 24 July 1967: 3. Print.

Staubmann, Helmut, ed. The Rolling Stones: Sociological Perspectives. Lanham, MD: Lexington, 2013. Print.

The Look of the Week. BBC One. 21 May 1967. Television.

Thornton, Sarah. Club Cultures: Music, Media and Subcultural Capital. Cambridge: Polity, 1995. Print. 
Turner, Steve. “Coming Under The Thumb: Mick Jagger.” You 20 September 1987.

<http://www.rocksbackpages.com/Library/Article/coming-under-the-thumb-mick-jagger>

Vyner, Harriet. Groovy Bob: The Life and Times of Robert Fraser. London: Faber and Faber, 2001. Print.

Weeks, Jeffrey. The World We Have Won: The Remaking of Erotic and Intimate Life.

London: Routledge, 2007. Print.

Weinhauer, Klaus. "Drug Consumption in London and Western Berlin during the 1960s and 1970s: Local and Transnational Perspectives." The Social History of Alcohol and Drugs: An Interdisciplinary Journal 21.2 (2006): 187-224. Print.

Wells, Simon. Butterfly on a Wheel: The Great Rolling Stones Drugs Bust. London:

Omnibus, 2011. Print.

Wheen, Francis. The Soul of Indiscretion: Tom Driberg - Poet, Philanderer, Legislator and Outlaw. London: Fourth Estate, 2001. Print.

Whiteley, Sheila, and Jedediah Sklower, ed. Countercultures and Popular Music. London: Routledge, 2016. Print.

Whiteley, Sheila. The Space between the Notes: Rock and the Counterculture. London: Routledge: 1992. Print.

Whitworth, Damian. "Times Article Saved the Stones, Says Richards." The Times 16 October 2010: 8-10. Print.

Wilcock, John (aka J.W.). “Jagger Saga.” Oz 6 (June 1967): 16. Print.

Williams, Chris. "Rolling Stones: R and B Champs.” New Musical Express 23 August 1963:

8. Print.

Willis, Paul. “The Cultural Meaning of Drug Use.” Resistance Through Rituals: Youth Subcultures in Postwar Britain. Ed. Stuart Hall and Tony Jefferson. London: Hutchinson, 1976. 106-118. Print. 
Wilson, Andrew. "Mixing the Medicine: The Unintended Consequence of Amphetamine Control on the Northern Soul Scene." The Internet Journal of Criminology (2008).

$<$ http://www.internetjournalofcriminology.com/Wilson\%20-

\%20Mixing\%20the\%20Medicine.pdf>

Wilson, Andrew. "Spontaneous Underground: An Introduction to London Psychedelic

Scenes, 1965-1968." Summer of Love: Psychedelic Art, Social Crisis and Counterculture in the 1960s. Ed. Christoph Grunenberg and Jonathan Harris. Liverpool: Liverpool University Press, 2005. 63-97. Print.

World In Action. Granada. 31 July 1967. Television.

Wyman, Bill and Ray Coleman. Stone Alone. New York: Viking, 1990. Print.

Young, Jock. The Drugtakers: The Social Meaning of Drug Use. London: MacGibbon and Kee, 1971. Print. 